\title{
Effects of manganese on maturation of porcine oocytes in vitro and their subsequent embryo development after parthenogenetic activation and somatic cell nuclear transfer
}

\author{
Muhammad QASIM ${ }^{1)}$, Jun-Xue JIN1, 2), Sanghoon LEE ${ }^{1,3)}$, Anukul TAWEECHAIPAISANKUL ${ }^{1)}$, \\ Erif Maha Nugraha SETYAWAN ${ }^{1)}$, Geon A KIM ${ }^{1)}$ and Byeong Chun LEE ${ }^{1)}$ \\ 1) Department of Theriogenology and Biotechnology, College of Veterinary Medicine, Seoul National University, \\ Seoul 08826, Republic of Korea \\ 2) Key Laboratory of Animal Cellular and Genetic Engineering of Heilongjiang Province, College of Life Science, \\ Northeast Agriculture University, Heilongjiang 150030, China \\ 3) Futuristic Animal Resource \& Research Center, Korea Research Institute of Bioscience and Biotechnology, \\ Chungcheongbuk-do 28116, Republic of Korea
}

\begin{abstract}
This study was carried out to examine the effects of manganese $(\mathrm{Mn})$ on the developmental competence of porcine oocytes during in vitro maturation (IVM) after parthenogenetic activation (PA) and somatic cell nuclear transfer (SCNT). Upon treatment of porcine oocytes with different concentrations $(0,3,6$, and $12 \mathrm{ng} / \mathrm{ml})$ of Mn during IVM, PA was performed to determine the optimum concentration. Following PA, the rate of blastocyst formation was higher significantly in treated porcine oocytes at $6 \mathrm{ng} / \mathrm{ml}$ of $\mathrm{Mn}$ than in other groups $(\mathrm{P}<0.05)$. However, there was no substantial difference in the cleavage rate and total blastocyst cell numbers among all groups. SCNT was performed using the optimal concentration of $\mathrm{Mn}$ from PA, which showed an improved blastocyst formation rate in treated oocytes compared to that in control group (P $<0.05)$. However, the cleavage rate and total cell numbers per blastocyst were not different between the control and the Mn treated groups after SCNT. Additionally, oocyte nuclear maturation, intracellular glutathione (GSH), and reactive oxygen species (ROS) levels were assessed. There was no significant difference observed in nuclear maturation among all the groups. However, enhanced intracellular GSH levels while lower levels of ROS were seen in the Mn treated group compared to the control group $(\mathrm{P}<0.05)$. Thus, these results indicate that $\mathrm{Mn}$ supplementation can improve the developmental competence of porcine PA and SCNT embryos by increasing GSH and decreasing ROS levels.
\end{abstract}

Key words: Antioxidant, Embryo development, Manganese (Mn), Porcine oocytes

(J. Reprod. Dev. 65: 259-265, 2019)

$\mathbf{H}$ umans and pigs share many common characteristics, including diet, body size, and brain size [1]. Pigs are believed to be the preferred disease model when compared with other species [2]. They are an ideal animal model for xenotransplantation, biomedical research $[3,4]$ and many other specific studies on human diseases [5, 6]. In vitro embryo production (IVP) is required to produce the animal models that can possibly reproduce the human pathology [7] such as cardiovascular diseases, cancers, diabetes mellitus, Alzheimer's disease, cystic fibrosis, and Duchenne muscular dystrophy [2]. Therefore, IVP has gained so much importance in recent years. Although there have been many improvements in porcine IVP protocols, the efficiency of embryo production is still much lower than in vivo embryo production $[8,9]$. The most important reason for this low efficiency is due to the oxidative stress [10] caused by

Received: January 7, 2019

Accepted: February 23, 2019

Published online in J-STAGE: March 21, 2019

(C)2019 by the Society for Reproduction and Development

Correspondence: B C Lee (e-mail: bclee@snu.ac.kr)

This is an open-access article distributed under the terms of the Creative Commons Attribution Non-Commercial No Derivatives (by-nc-nd) License. (CC-BY-NC-ND 4.0: https://creativecommons.org/licenses/by-nc-nd/4.0/) excessive production of reactive oxygen species (ROS) [11] during in vitro oocyte maturation. Therefore, adding free radical scavengers is needed to protect oocytes and to limit the detrimental effects of ROS [12]. Various kinds of antioxidants, for example, melatonin [13], spermine, [14], resveratrol [15], zinc [16], and copper [17] have been used to improve the quality of in vitro produced embryos.

Manganese $(\mathrm{Mn})$ is a trace mineral naturally present in food, especially in cereals, nuts, and vegetables [18]. This is required for many physiological processes [19] such as metabolism of lipids, proteins, and carbohydrates [20], bone growth, energy metabolism, reproduction, and antioxidant defenses [21]. Mn is an essential element required to increase the activity of manganese superoxide dismutase (MnSOD), a major antioxidant enzyme located in mitochondria. Moreover, MnSOD activity can be enhanced through the mitochondrial protein influx [22-24] and protects the mammalian cells from the damaging effects of ROS [25]. The MnSOD activity is not only related to levels of superoxide anion but also to the glucose and oxygen consumption in cells [26]. The superoxide dismutase (SOD) activity was increased in cumulus cells when the maturation media was supplemented with Mn [27]. Moreover, the DNA integrity can be preserved and developmental competence of bovine oocytes to blastocyst stage can be increased through the antioxidant effect of Mn 
in cumulus oocyte complexes (COCs) [28]. Furthermore, the addition of $\mathrm{Mn}$ to maturation medium not only improved the competence of oocytes to be fertilized but also decreased the frequency of apoptotic cumulus cells [29]. Mn functions as a cofactor for several important enzymes such as arginase, pyruvate decarboxylase, and glutamine synthase [30], which are involved in DNA synthesis [31] and DNA protection [25]. Any abnormality in the Mn homeostasis can lead to the misregulation of cell cycle progression [32]. Recently, few studies have been conducted regarding supplementation of $\mathrm{Mn}$ in rat [33], cattle [34], and dog [35] in vivo and in vitro in bovine embryos [28]. It has been reported that the presence of micronutrient such as $\mathrm{Mn}$, not only protects the DNA integrity but also improved the bovine oocyte quality and embryo development to blastocyst stage with increased intracellular levels of glutathione (GSH) [27]. However, no previous study has shown the effects of Mn supplementation during in vitro maturation (IVM) of porcine oocytes and their subsequent embryo development after parthenogenetic activation (PA) and somatic cell nuclear transfer (SCNT). Therefore, we designed this study to observe the effects of Mn supplementation during IVM of porcine oocytes on their nuclear maturation, GSH, and ROS levels in mature porcine oocytes, and to observe the development of embryos after performing PA and SCNT.

\section{Material and Methods}

\section{Chemicals}

All chemicals and reagents used in this study were purchased from Sigma-Aldrich (St. Louis, MO, USA) unless otherwise specified.

\section{Oocyte collection and IVM}

Ovaries were collected from a local slaughterhouse in collection vials containing normal saline kept at $32-35^{\circ} \mathrm{C}$ and were transported to the laboratory. Aspiration of COCs from antral follicle (3-6 mm in diameter) was performed using an 18-gauge needle. The contents collected were poured into $50 \mathrm{ml}$ conical tube and held at $37^{\circ} \mathrm{C}$ until they settle down. The supernatant was discarded, and cellular contents were washed in tissue culture medium-199 (TCM-199; Invitrogen, Carlsbad, CA, USA) containing $2 \mathrm{mM}$ sodium bicarbonate, $10 \mathrm{mM}$ $\mathrm{N}$-(2-hydroxyethyl) piperazine-N' - (2-ethanesulfonic acid; HEPES), $5 \mathrm{mM}$ sodium hydroxide, $1 \%$ Pen-Strep (Invitrogen), and $0.3 \%$ polyvinyl alcohol (PVA). After washing, COCs with a homogeneous cytoplasm and at least three layers of cumulus cells were examined under a stereomicroscope. COCs were transferred into $500 \mu \mathrm{l}$ of maturation medium comprising TCM-199 supplemented with 0.91 $\mathrm{mM}$ sodium pyruvate, $5 \mu \mathrm{l} / \mathrm{ml}$ insulin-transferrin-selenium solution (ITS-A) 100X (Invitrogen), $0.57 \mathrm{mM}$ cysteine, $10 \mathrm{ng} / \mathrm{ml}$ epidermal growth factor (EGF), $10 \mathrm{IU} / \mathrm{ml}$ human chorionic gonadotropin (hCG), $10 \mathrm{IU} / \mathrm{ml}$ equine chorionic gonadotropin (eCG), $10 \%$ porcine follicular fluid (vol/vol), and various concentrations (0, 3, 6, and 12 $\mathrm{ng} / \mathrm{mL}$ ) of Mn (II) sulfate monohydrate (M7899) purchased from Sigma-Aldrich in the treatment groups, after diluting in TCM-199. For IVM, COCs were then cultured at $38.5^{\circ} \mathrm{C}$ in $5 \% \mathrm{CO}_{2}$ in humidified air for $44 \mathrm{~h}$. Following first $22 \mathrm{~h}$, COCs were cultured for further $22 \mathrm{~h}$ in hormone-free IVM medium.

\section{Evaluation of porcine oocyte maturation}

After $44 \mathrm{~h}$ of culture in IVM medium, porcine oocytes were denuded by gentle pipetting using $0.1 \%$ hyaluronidase in Tyrode's albumin lactate pyruvate (TALP) medium with HEPES buffer. The denuded oocytes were then stained using $5 \mu \mathrm{g} / \mathrm{ml}$ of bisbenzimide (Hoechst 33342 ) in TALP-HEPES for approximately $10 \mathrm{~min}$. A fluorescence microscope (Nikon, Tokyo, Japan) was used to evaluate the stained oocytes. We repeated the experiment for six times.

\section{Measurement of intracellular ROS and GSH levels}

Denuded oocytes at metaphase II (MII) stage were selected to determine intracellular levels of GSH and ROS after staining with CellTracker Blue $\mathrm{CMF}_{2} \mathrm{HC}$ (4-chloromethyl-6.8-difluoro7-hydroxycoumarin; Invitrogen), and $\mathrm{H}_{2}$ DCFDA (2', 7'-dichlorodihydrofluorescein diacetate; Invitrogen), respectively. TALP containing $10 \mu \mathrm{M} \mathrm{H}_{2}$ DCFDA and $10 \mu \mathrm{M}$ CellTracker Blue was used as the incubation medium and 10 MII stage oocytes from each treatment group were transferred to these media and incubated in the dark for $30 \mathrm{~min}$. After incubation, stained oocytes were washed three times in TALP and approximately four oocytes were placed into $4 \mu \mathrm{l}$ droplet of TALP-HEPES and fluorescence was observed under an epifluorescence microscope (TE2000-S; Nikon) with UV filters (460 nm for ROS and $370 \mathrm{~nm}$ for GSH). Image J software (Version 1.49q; National Institutes of Health, Bethesda, MD) was used to observe the fluorescence intensities of oocytes and normalized to control embryos.

\section{Parthenogenetic activation of oocytes}

Denuded oocytes with homogeneous cytoplasm and an extruded first polar body (PB) were selected and gradually equilibrated to avoid the somatic shock [36] in the activation solution containing $0.28 \mathrm{M}$ mannitol, $0.5 \mathrm{mM}$ HEPES, $0.1 \mathrm{mM} \mathrm{CaCl}_{2}$, and $0.1 \mathrm{mM} \mathrm{MgSO}_{4}$. The activation chamber was placed on a heating stage and filled with an activation solution after connecting two electrodes spaced 3.2 $\mathrm{mm}$ apart. Oocytes were placed in the chamber and activated with a single direct current (DC) pulse of $1.5 \mathrm{kV} / \mathrm{cm}$ for $60 \mu \mathrm{sec}$ using a BTX Electro-Cell Manipulator 2001 (BTX, San Diego, CA, USA). After activation, oocytes were washed twice with porcine zygote medium-5 (PZM-5; Funakoshi, Tokyo, Japan) and approximately $50-60$ electrically activated oocytes were placed in $500 \mu 1$ of PZM-5 and cultured under a humidified atmosphere of $5 \% \mathrm{CO}_{2}, 5 \% \mathrm{O}_{2}$, and $90 \% \mathrm{~N}_{2}$ at $38.5^{\circ} \mathrm{C}$ for 7 days.

\section{Preparation of donor cell}

Fibroblast cells derived from the skin of a pig were used as donors. Briefly, the skin was chopped into small pieces and washed in PBS three times. This was cultured in a humidified air atmosphere incubator with $5 \% \mathrm{CO}_{2}$ at $38^{\circ} \mathrm{C}$ in air in Dulbecco's modified Eagle's medium (DMEM; Gibco, culture medium) containing 10\% fetal bovine serum (FBS; Gibco, culture medium; vol/vol), $1 \mathrm{mM}$ sodium pyruvate, and $100 \mathrm{IU} / \mathrm{ml}$ each of penicillin and streptomycin. Cells between passages 5 and 7 were used for SCNT. Immediately before SCNT, single cell suspensions were prepared by standard trypsinization.

\section{Somatic cell nuclear transfer}

Denuded oocytes with clear perivitelline space, evenly distributed 
cytoplasm, and an extruded PB were selected and washed twice in TALP medium. These oocytes were stained with $5 \mu \mathrm{g} / \mathrm{ml}$ of Hoechst 33342 and kept in the dark for $10 \mathrm{~min}$. Oocytes were transferred into TALP medium containing $7.5 \mathrm{mg} / \mathrm{ml}$ of cytochalasin B and observed under an inverted microscope equipped with epifluorescence. An oocyte was held in place with a holding micropipette and the zona pellucida was partially dissected with a fine glass needle to make a slit near the first PB. Then the first PB was aspirated with an aspiration pipette along with a small portion of cytoplasm containing MII chromosomes. After enucleation of an oocyte, a single trypsinized skin fibroblast with a smooth outline was injected into the perivitelline space. All these oocytes were equilibrated in a fusion solution consisting of $0.28 \mathrm{M}$ mannitol solution with $0.5 \mathrm{mM}$ HEPES and $0.01 \mathrm{mM} \mathrm{MgSO}_{4}$ and then fused with a single DC pulse of $1.2 \mathrm{kV} /$ $\mathrm{cm}$ for $30 \mu \mathrm{sec}$ using an electrical pulsing machine (LF101; Nepa Gene, Chiba, Japan). After $30 \mathrm{~min}$, fused couplets were equilibrated in the activation solution $(0.28 \mathrm{M}$ mannitol solution containing 0.5 mM HEPES, $0.1 \mathrm{mM} \mathrm{CaCl}_{2}$, and $0.1 \mathrm{mM} \mathrm{MgSO}_{4}$ ) for $4 \mathrm{~min}$. After activation, they were transferred into a chamber with activation solution and two electrodes and were activated with a single DC pulse of $1.5 \mathrm{kV} / \mathrm{cm}$ for $30 \mu \mathrm{sec}$ using a BTX Electro-Cell Manipulator 2001 (BTX). Electrically activated embryos were washed in PZM-5 and transferred to the culture medium at $38.5^{\circ} \mathrm{C}$ in a humidified environment with $5 \% \mathrm{O}_{2}, 5 \% \mathrm{CO}_{2}$, and $90 \% \mathrm{~N}_{2}$ for 7 days. Total blastocyst cell numbers were counted on day 7. Blastocysts were washed in TALP and stained with $5 \mu \mathrm{g} / \mathrm{ml}$ of Hoechst 33342 in TALP-HEPES for $10 \mathrm{~min}$ in the dark. After a final wash with TALP, the blastocysts were mounted on a glass slide in a drop of $100 \%$ glycerol, compressed gently with a coverslip and observed under a fluorescence microscope.

\section{Experimental design}

In experiment 1 , we evaluated the effects of different concentrations $(0,3,6$, and $12 \mathrm{ng} / \mathrm{ml})$ of $\mathrm{Mn}$ treatment during IVM on the oocyte nuclear maturation rate by measuring the frequency of first $\mathrm{PB}$ extrusion. In experiment 2, we added Mn during PA to explore the optimal concentration. In experiment 3, we determined the levels of $\mathrm{GSH}$ and ROS in the control group and $\mathrm{Mn}(6 \mathrm{ng} / \mathrm{ml})$ treated groups, to examine the quality of oocytes. In experiment 4 , we determined the effects of Mn during IVM on SCNT embryos.

\section{Statistical analysis}

Each experiment was repeated at least six times. The data are expressed as the mean \pm standard error of the mean (SEM). Values were analyzed using univariate analysis of variance (ANOVA) followed by Duncan's multiple range test using SPSS Statistics 17.0 software (SPSS, Chicago, IL, USA). Differences in SCNT blastocyst rates were compared by Student's $t$-test. $\mathrm{P}<0.05$ was considered statistically significant.

\section{Results}

\section{Effect of Mn supplementation on nuclear maturation of porcine oocytes}

A total of 720 oocytes were used in 6 replicates for the evaluation of nuclear maturation (Fig. 1). The nuclear maturation ranged from
$89.4 \%$ to $93.3 \%$ without showing any significant differences among the groups (Table 1).

\section{Effect of Mn supplementation during IVM on developmental} competence of parthenogenetic embryos

We attempted to find the optimum concentration of Mn after treating oocytes with different concentrations $(0,3,6$ and $12 \mathrm{ng} / \mathrm{ml})$ of $\mathrm{Mn}$ during IVM. The blastocyst formation rate was significantly higher in the group treated with $6 \mathrm{ng} / \mathrm{ml} \mathrm{Mn} \mathrm{compared} \mathrm{with} \mathrm{the} \mathrm{control}$ and $12 \mathrm{ng} / \mathrm{ml} \mathrm{Mn} \mathrm{treated} \mathrm{groups}(25.85 \%, 17.78 \%$, and $16.34 \%$, respectively; $\mathrm{P}<0.05$; Table 2). However, no significant difference was found in cleavage rates and total blastocyst cell number among all the groups.

\section{Effect of Mn supplementation on intracellular levels of GSH and $R O S$}

The intracellular levels of GSH were significantly higher in the group treated with $6 \mathrm{ng} / \mathrm{ml} \mathrm{Mn} \mathrm{compared} \mathrm{with} \mathrm{the} \mathrm{control} \mathrm{group}$ $(1.10 \pm 1.01$ pixels/oocyte $v s .1 .00 \pm 0.30$ pixels/oocyte, $\mathrm{P}<0.05)$. However, the levels of ROS were lower in the group treated with 6 $\mathrm{ng} / \mathrm{ml} \mathrm{Mn} \mathrm{compared} \mathrm{with} \mathrm{control} \mathrm{group}(1.00 \pm 0.03$ pixels/oocyte vs. $0.78 \pm 0.25$ pixels/oocyte, $\mathrm{P}<0.05$ ) (Fig. 2).

\section{Effect of Mn supplementation during IVM on embryonic development competence after SCNT}

Based on the optimal concentration from PA, we treated oocytes with $6 \mathrm{ng} / \mathrm{ml} \mathrm{Mn}$ during IVM and performed SCNT. The embryonic development rate was compared with the control group. As shown in Table 3, the blastocyst formation rate is significantly higher in the group treated with $6 \mathrm{ng} / \mathrm{ml} \mathrm{Mn}$ than that of the control group. However, there was no effect on cleavage rates and total cell numbers per blastocyst.

\section{Discussion}

For successful in vitro production of embryos, the culture conditions during IVM play a significant role. In this study, we demonstrated that Mn treatment during IVM had beneficial effects on the developmental competence of porcine oocytes. GSH levels were increased while ROS levels were decreased by treating the oocytes with $6 \mathrm{ng} / \mathrm{ml} \mathrm{Mn}$ during IVM. In addition, Mn also improved the in vitro developmental competence of PA and SCNT embryos.

In vitro culture systems require high oxygen concentration for their maintenance as compared to in vivo culture systems, resulting in an increased production of ROS [37]. Oxidative stress from excessive ROS production is the major hindrance to successful porcine embryo production [11]. There is a link between oxygen concentration in in vitro culture systems and oxidative stress induced by ROS such as superoxide anion $\left(\mathrm{O}_{2}{ }^{-}\right)$or hydrogen peroxide $\left(\mathrm{H}_{2} \mathrm{O}_{2}\right)$ [12] that leads to the impairment of oocyte maturation [38]. Oocytes are sensitive to oxidative stress during maturation and the occurrence of oxidative stress is considered to be a very important parameter in evaluating the health of an oocyte [39].To protect oocytes from the damaging effects of ROS, the use of agents such as antioxidants [40] that can trap free radicles is a prerequisite [11]. Mn is a very important part of various metalloenzymes including MnSOD [41] 

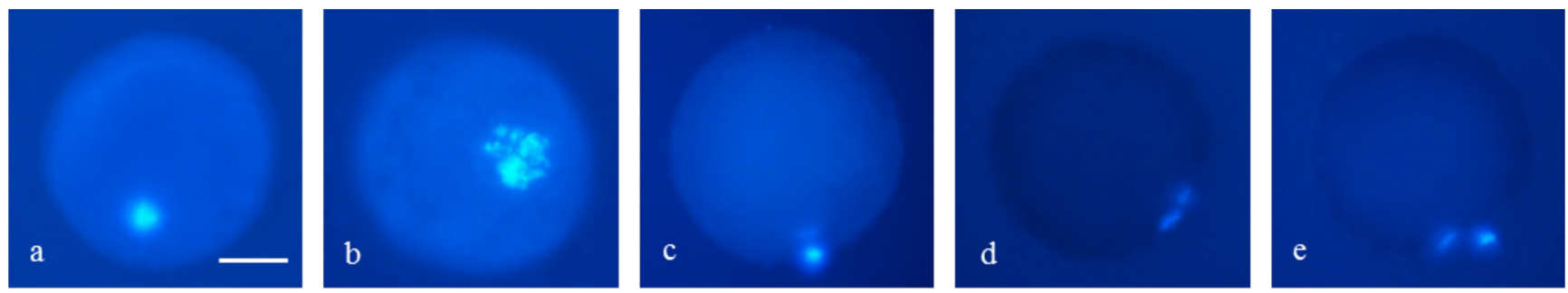

Fig. 1. Chromatin configuration of porcine oocytes stained with Hoechst 33342 after 44 h of IVM. (a) Germinal vesicle. (b) Germinal vesicle breakdown. (c) Metaphase I. (d) Anaphase to Telophase I. (e) Metaphase II. Scale bar indicates $100 \mu \mathrm{m}$.

Table 1. Effect of manganese treatment on nuclear maturation of porcine oocytes during IVM

\begin{tabular}{cccrrr}
\hline \multirow{2}{*}{$\begin{array}{c}\text { Manganese concentration } \\
(\mathrm{ng} / \mathrm{ml})\end{array}$} & $\begin{array}{c}\text { No. of oocytes } \\
\text { cultured }^{1}\end{array}$ & \multicolumn{3}{c}{ No. (mean \pm SEM, \%) of oocytes at the stage of } \\
\cline { 3 - 6 } & 180 & $0(0.0 \pm 0.0)$ & $9(5.0 \pm 1.1)$ & $10(5.5 \pm 1.1)$ & $161(89.4 \pm 2.0)$ \\
\hline 0 & 180 & $1(0.1 \pm 0.1)$ & $8(5.0 \pm 1.1)$ & $7(3.8 \pm 1.0)$ & $164(91.1 \pm 1.4)$ \\
3 & 180 & $0(0.0 \pm 0.0)$ & $10(5.5 \pm 0.7)$ & $5(2.7 \pm 1.3)$ & $165(91.6 \pm 1.6)$ \\
6 & 180 & $0(0.0 \pm 0.0)$ & $6(3.3 \pm 1.7)$ & $6(3.3 \pm 0.8)$ & $168(93.3 \pm 2.2)$ \\
12 & &
\end{tabular}

${ }^{1}$ Experiment was replicated 6 times. ${ }^{2}$ GV-GVBD, Germinal vesicle-Germinal vesicle breakdown. ${ }^{3}$ MI, Metaphase I. ${ }^{4}$ AnaTelo, Anaphase-Telophase I. ${ }^{5}$ MII, Metaphase II.

(A)

Control
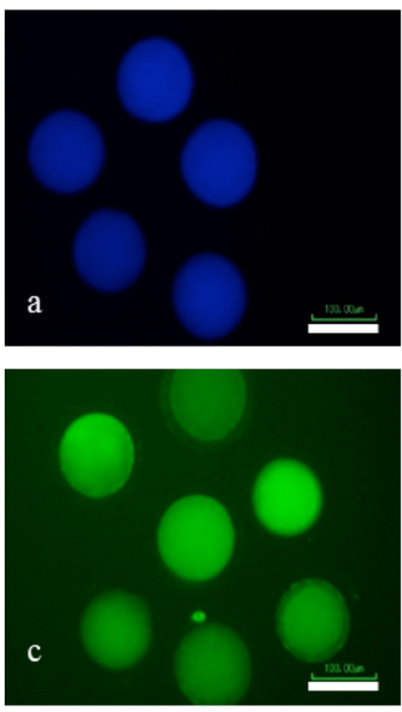

$\mathrm{Mn}$
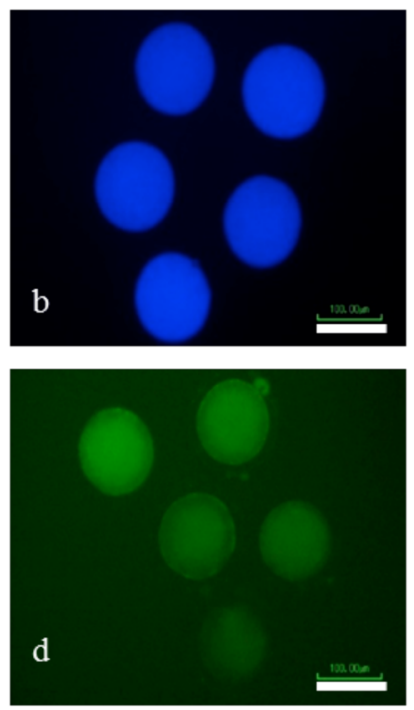

(B)

Control

$\square \mathrm{Mn}$

GSH

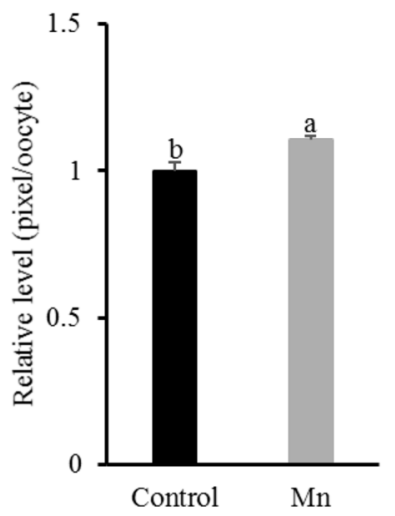

ROS

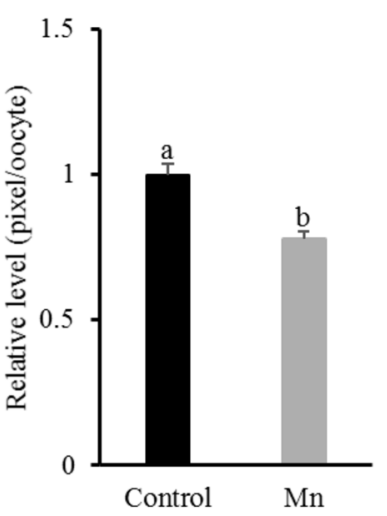

Fig. 2. Epifluorescent photomicrographic images of in vitro matured porcine oocytes. (A) Matured oocytes are stained with CellTracker Blue (a-b) and 2', 7'-dichlorodihydrofluorescein diacetate ( $\mathrm{H}_{2}$ DCFDA; c-d) to detect intracellular glutathione (GSH) and reactive oxygen species (ROS) levels, respectively. In vitro matured oocytes derived from the control (a and c) and $6 \mathrm{ng} / \mathrm{ml}$ of $\mathrm{Mn}$ treated group (b and d). (B) Effects of Mn on the intracellular levels of GSH and ROS during IVM of in vitro matured porcine oocytes. Bars with different letters (a and b) represent significant differences within the respective endpoint (GSH or ROS; $(\mathrm{P}<0.05)$ ). Scale bars indicate $100 \mu \mathrm{m}$. Error bars show the standard error of the mean. 
Table 2. Effect of manganese treatment during IVM on embryonic development after PA

\begin{tabular}{ccccc}
\hline $\begin{array}{c}\text { Manganese concentration } \\
(\mathrm{ng} / \mathrm{ml})\end{array}$ & $\begin{array}{c}\text { No. of } \\
\text { embryos cultured }\end{array}$ & \multicolumn{2}{c}{ No. of embryos developed to (mean \pm SEM, \%) } & \multirow{2}{*}{$\begin{array}{c}\text { Total cell No. (mean } \pm \text { SEM) } \\
\text { in blastocyst }\end{array}$} \\
\cline { 3 - 4 } 0 & 198 & $145(74.07 \pm 3.75)$ & $34(17.78 \pm 1.57)^{\mathrm{b}}$ & $49.40 \pm 1.27$ \\
3 & 194 & $148(75.99 \pm 3.08)$ & $37(20.20 \pm 2.88)^{\mathrm{ab}}$ & $51.04 \pm 1.03$ \\
6 & 199 & $162(81.20 \pm 3.23)$ & $48(25.85 \pm 1.99)^{\mathrm{a}}$ & $50.90 \pm 1.09$ \\
12 & 201 & $139(75.12 \pm 7.22)$ & $28(16.34 \pm 3.48)^{\mathrm{b}}$ & $49.73 \pm 1.22$ \\
\hline
\end{tabular}

Values are listed as mean \pm SEM of six replicates. ${ }^{a}, b$ Values within a column with different superscripts differ significantly at $\mathrm{P}<0.05$.

Table 3. Effect of manganese treatment during IVM on embryonic development after SCNT

\begin{tabular}{ccccc}
\hline $\begin{array}{c}\text { Manganese concentration } \\
(\mathrm{ng} / \mathrm{ml})\end{array}$ & $\begin{array}{c}\text { No. of } \\
\text { embryos cultured }\end{array}$ & \multicolumn{2}{c}{ No. of embryos developed to (mean \pm SEM, \%) } & \multirow{2}{*}{$\begin{array}{c}\text { Total cell no. (mean } \pm \text { SEM) } \\
\text { in blastocyst }\end{array}$} \\
\cline { 3 - 4 } & 197 & $150(75.93 \pm 3.75)$ & $33(16.55 \pm 2.00)^{\mathrm{b}}$ & $52.06 \pm 2.05$ \\
6 & 202 & $167(82.43 \pm 2.02)$ & $46(22.91 \pm 2.18)^{\mathrm{a}}$ & $56.85 \pm 3.74$ \\
\hline
\end{tabular}

Values are listed as mean \pm SEM of six replicates. ${ }^{a}$ b Values within a column with different superscripts differ significantly at $\mathrm{P}<0.05$.

and acts as a metal binding site [42]. Since Mn increases MnSOD activity, it caused a considerable reduction in ROS levels when porcine IVM media was supplemented with Mn. MnSOD is a very important enzyme that plays a key role in reducing ROS effects [25, 43] and is active only in the presence of manganese [44]. It has been studied that Mn decreases the oxidative stress depending on the cell type and concentration used [43].

GSH is a nonproteinous sulfhydryl compound that plays an important role in protecting the mammalian cells from oxidative damage [45]; it has been shown to improve porcine embryonic development [46]. It is also the major intracellular free thiol that plays a key role in DNA and protein synthesis [47]. Abeydeera et al. observed increased fertilization and blastocyst development rate through an increased level of GSH in porcine oocyte during IVM [48]. The maturation competence of porcine oocytes can be predicted by measuring their GSH levels [14]. Porcine embryos are considered to be more sensitive to lipid peroxidation because of their high fatty acid content [49]; therefore, the beneficial effects of antioxidants are comparatively higher in porcine embryos than the other mammalian embryos. ROS generation during maturation of oocytes may lead to cell damage by promoting lipid peroxidation and inactivation of enzymes [50] while Mn lowers lipid peroxidation [51] and accelerates the enzyme activity of the ascorbate-GSH cycle [52]. All these findings indicate that there is a positive correlation between the level of GSH and blastocyst development. When we cultured COCs in IVM media supplemented with $6 \mathrm{ng} / \mathrm{ml} \mathrm{Mn}$, intracellular GSH levels in treatment group had increased compared with those in control group.

Besides, increasing levels of GSH, decreasing levels of ROS, and $\mathrm{Mn}$ treatment also improved the rate of embryonic development to blastocysts after PA. Based on PA results, we treated the IVM media with Mn and performed SCNT, which resulted in the improved blastocyst formation rate. This showed that the effects of $\mathrm{Mn}$ are not limited only to parthenogenetic embryos. However, increase in GSH level improves cytoplasmic maturation in oocytes
[14] though there is a link between the extrusion of first PB and nuclear maturation as it occurs during nuclear maturation (MII) [53]. Supplementation of Mn in IVM media did not improve the nuclear maturation but expressed its beneficial effects on oocytes by improving the cytoplasmic maturation, which in turn enhanced the blastocyst formation rates.

After treating IVM media with different concentrations of Mn, PA and SCNT embryos showed significantly higher blastocyst formation rates at $6 \mathrm{ng} / \mathrm{ml}$ of $\mathrm{Mn}$. However, there was no significant difference in the cleavage rates and blastocyst cell numbers among the groups. Ability to develop to blastocyst stage is a good indicator of the developmental capacity of oocytes. Moreover, Mn treatment showed that it improved the capacity of embryos to develop to the blastocyst stage but did not influence the cleavage rate. The differential effects of Mn on cleavage and blastocyst rate might be the reason for zygote development to be dependent on the factors stored in the oocytes before cleavage, which activate the genome of the zygote [54]. Therefore, Mn treatment might show little influence on the cleavage rate. Cattle oocytes matured with Mn supplementation in IVM medium did not improve the cleavage rate [28] and other antioxidants used in porcine and bovine IVM medium showed the same result $[16,17]$. Our results are consistent with the previous study with bovine oocytes showing that embryonic development was higher in Mn-treated IVM media [28].

Therefore, in this study, we found the optimal concentration of Mn required during IVM of porcine oocytes. We found that adding $6 \mathrm{ng} / \mathrm{ml} \mathrm{Mn}$ to porcine IVM media improved the rate of blastocyst formation after PA and SCNT by decreasing ROS levels and increasing the levels of GSH.

\section{Acknowledgments}

The authors appreciate the efforts and assistance of Bo Mi Woo and Do Yeon Kim for their technical support. This study was supported by National Research Foundation (\#2016M3A9B6903410; 
2018R1D1A1B07048765), the Research Institute for Veterinary Science, and BK21 PLUS Program.

\section{References}

1. Schubert R, Frank F, Nagelmann N, Liebsch L, Schuldenzucker V, Schramke S, Wirsig M, Johnson H, Kim EY, Ott S, Hölzner E, Demokritov SO, Motlik J, Faber C, Reilmann R. Neuroimaging of a minipig model of Huntington's disease: Feasibility of volumetric, diffusion-weighted and spectroscopic assessments. J Neurosci Methods 2016; 265: 46-55. [Medline] [CrossRef]

2. Perleberg $\mathbf{C}$, Kind A, Schnieke A. Genetically engineered pigs as models for human disease. Dis Model Mech 2018; 11: 11. [Medline] [CrossRef]

3. Whyte JJ, Prather RS. Genetic modifications of pigs for medicine and agriculture. $\mathrm{Mol}$ Reprod Dev 2011; 78: 879-891. [Medline] [CrossRef]

4. Nowak-Imialek M, Niemann H. Pluripotent cells in farm animals: state of the art and future perspectives. Reprod Fertil Dev 2012; 25: 103-128. [Medline] [CrossRef]

5. Ekser B, Rigotti P, Gridelli B, Cooper DKC. Xenotransplantation of solid organs in the pig-to-primate model. Transpl Immunol 2009; 21: 87-92. [Medline] [CrossRef]

6. Nohalez A, Martinez CA, Parrilla I, Roca J, Gil MA, Rodriguez-Martinez H, Martinez EA, Cuello C. Exogenous ascorbic acid enhances vitrification survival of porcine in vitro-developed blastocysts but fails to improve the in vitro embryo production outcomes. Theriogenology 2018; 113: 113-119. [Medline] [CrossRef]

7. Polejaeva IA, Chen S-H, Vaught TD, Page RL, Mullins J, Ball S, Dai Y, Boone J, Walker S, Ayares DL, Colman A, Campbell KH. Cloned pigs produced by nuclear transfer from adult somatic cells. Nature 2000; 407: 86-90. [Medline] [CrossRef]

8. Marques MG, Nicacio AC, de Oliveira VP, Nascimento AB, Caetano HV, Mendes CM, Mello MR, Milazzotto MP, Assumpção ME, Visintin JA. In vitro maturation of pig oocytes with different media, hormone and meiosis inhibitors. Anim Reprod Sci 2007; 97: 375-381. [Medline] [CrossRef]

9. Grupen CG. The evolution of porcine embryo in vitro production. Theriogenology 2014; 81: 24-37. [Medline] [CrossRef]

10. Wu GQ, Jia BY, Li JJ, Fu XW, Zhou GB, Hou YP, Zhu SE. L-carnitine enhances oocyte maturation and development of parthenogenetic embryos in pigs. Theriogenology 2011; 76: 785-793. [Medline] [CrossRef]

11. Ozawa M, Nagai T, Fahrudin M, Karja NWK, Kaneko H, Noguchi J, Ohnuma K, Kikuchi K. Addition of glutathione or thioredoxin to culture medium reduces intracellular redox status of porcine IVM/IVF embryos, resulting in improved development to the blastocyst stage. Mol Reprod Dev 2006; 73: 998-1007. [Medline] [CrossRef]

12. Takahashi M, Nagai T, Okamura N, Takahashi H, Okano A. Promoting effect of betamercaptoethanol on in vitro development under oxidative stress and cystine uptake of bovine embryos. Biol Reprod 2002; 66: 562-567. [Medline] [CrossRef]

13. Kang JT, Koo OJ, Kwon DK, Park HJ, Jang G, Kang SK, Lee BC. Effects of melatonin on in vitro maturation of porcine oocyte and expression of melatonin receptor RNA in cumulus and granulosa cells. J Pineal Res 2009; 46: 22-28. [Medline] [CrossRef]

14. Jin JX, Lee S, Khoirinaya C, Oh A, Kim GA, Lee BC. Supplementation with spermine during in vitro maturation of porcine oocytes improves early embryonic development after parthenogenetic activation and somatic cell nuclear transfer. J Anim Sci 2016; 94: 963-970. [Medline] [CrossRef]

15. Lee S, Park EJ, Moon JH, Kim SJ, Song K, Lee BC. Sequential treatment with resveratrol-trolox improves development of porcine embryos derived from parthenogenetic activation and somatic cell nuclear transfer. Theriogenology 2015; 84: 145-154. [Medline] [CrossRef]

16. Jeon Y, Yoon JD, Cai L, Hwang S-U, Kim E, Zheng Z, Lee E, Kim DY, Hyun S-H. Supplementation of zinc on oocyte in vitro maturation improves preimplatation embryonic development in pigs. Theriogenology 2014; 82: 866-874. [Medline] [CrossRef]

17. Picco SJ, Rosa DE, Anchordoquy JP, Anchordoquy JM, Seoane A, Mattioli GA, Furnus CC. Effects of copper sulphate concentrations during in vitro maturation of bovine oocytes. Theriogenology 2012; 77: 373-381. [Medline] [CrossRef]

18. Santamaria AB. Manganese exposure, essentiality \& toxicity. Indian J Med Res 2008; 128: 484-500. [Medline]

19. Liao S-L, Chen C-J. Manganese stimulates stellation of cultured rat cortical astrocytes. Neuroreport 2001; 12: 3877-3881. [Medline] [CrossRef]

20. Erikson KM, Syversen T, Aschner JL, Aschner M. Interactions between excessive manganese exposures and dietary iron-deficiency in neurodegeneration. Environ Toxicol Pharmacol 2005; 19: 415-421. [Medline] [CrossRef]

21. Horning KJ, Caito SW, Tipps KG, Bowman AB, Aschner M. Manganese Is Essential for Neuronal Health. Annu Rev Nutr 2015; 35: 71-108. [Medline] [CrossRef]

22. Au C, Benedetto A, Aschner M. Manganese transport in eukaryotes: the role of DMT1. Neurotoxicology 2008; 29: 569-576. [Medline] [CrossRef]

23. Gao T, Wang F, Li S, Luo X, Zhang K. Manganese regulates manganese-containing superoxide dismutase (MnSOD) expression in the primary broiler myocardial cells. Biol Trace Elem Res 2011; 144: 695-704. [Medline] [CrossRef]

24. Candas D, Li JJ. MnSOD in oxidative stress response-potential regulation via mitochondrial protein influx. Antioxid Redox Signal 2014; 20: 1599-1617. [Medline] [CrossRef]

25. Holley AK, Bakthavatchalu V, Velez-Roman JM, St Clair DK. Manganese superoxide dismutase: guardian of the powerhouse. Int J Mol Sci 2011; 12: 7114-7162. [Medline] [CrossRef]

26. Sarsour EH, Kalen AL, Goswami PC. Manganese superoxide dismutase regulates a redox cycle within the cell cycle. Antioxid Redox Signal 2014; 20: 1618-1627. [Medline] [CrossRef]

27. Anchordoquy JP, Anchordoquy JM, Sirini MA, Testa JA, Peral-García P, Furnus CC. The importance of manganese in the cytoplasmic maturation of cattle oocytes: blastocyst production improvement regardless of cumulus cells presence during in vitro maturation. Zygote 2016; 24: 139-148. [Medline] [CrossRef]

28. Anchordoquy JP, Anchordoquy JM, Sirini MA, Mattioli G, Picco SJ, Furnus CC. Effect of different manganese concentrations during in vitro maturation of bovine oocytes on DNA integrity of cumulus cells and subsequent embryo development. Reprod Domest Anim 2013; 48: 905-911. [Medline] [CrossRef]

29. Anchordoquy JP, Anchordoquy JM, Picco SJ, Sirini MA, Errecalde AL, Furnus CC. Influence of manganese on apoptosis and glutathione content of cumulus cells during in vitro maturation in bovine oocytes. Cell Biol Int 2014; 38: 246-253. [Medline] [CrossRef]

30. Díez AM, Campo ML, Soler G. Trypsin digestion of arginase: evidence for a stable conformation manganese directed. Int J Biochem 1992; 24: 1925-1932. [Medline] [CrossRef]

31. Cailliatte R, Schikora A, Briat J-F, Mari S, Curie C. High-affinity manganese uptake by the metal transporter NRAMP1 is essential for Arabidopsis growth in low manganese conditions. Plant Cell 2010; 22: 904-917. [Medline] [CrossRef]

32. García-Rodríguez N, Díaz de la Loza MC, Andreson B, Monje-Casas F, Rothstein R, Wellinger RE. Impaired manganese metabolism causes mitotic misregulation. $J$ Biol Chem 2012; 287: 18717-18729. [Medline] [CrossRef]

33. Malecki EA, Greger JL. Manganese protects against heart mitochondrial lipid peroxidation in rats fed high levels of polyunsaturated fatty acids. J Nutr 1996; 126: 27-33. [Medline] [CrossRef]

34. Hackbart KS, Ferreira RM, Dietsche AA, Socha MT, Shaver RD, Wiltbank MC, Fricke PM. Effect of dietary organic zinc, manganese, copper, and cobalt supplementation on milk production, follicular growth, embryo quality, and tissue mineral concentrations in dairy cows. J Anim Sci 2010; 88: 3856-3870. [Medline] [CrossRef]

35. Kim MJ, Oh HJ, Park JE, Kim GA, Park EJ, Jang G, Lee BC. Effects of mineral supplements on ovulation and maturation of dog oocytes. Theriogenology 2012; 78: 110-115. [Medline] [CrossRef]

36. Kwon D, Saadeldin IM, Kim SJ, Park SJ, Kang JT, Park HJ, Moon JH, Koo OJ, Jang G, Lee BC. Optimizing electrical activation of porcine oocytes by adjusting preand post-activation mannitol exposure times. Reprod Domest Anim 2014; 49: 995-999. [Medline] [CrossRef]

37. Tatemoto H, Muto N, Sunagawa I, Shinjo A, Nakada T. Protection of porcine oocytes against cell damage caused by oxidative stress during in vitro maturation: role of superoxide dismutase activity in porcine follicular fluid. Biol Reprod 2004; 71: 1150-1157. [Medline] [CrossRef]

38. Alvarez GM, Morado SA, Soto MP, Dalvit GC, Cetica PD. The control of reactive oxygen species influences porcine oocyte in vitro maturation. Reprod Domest Anim 2015; 50: 200-205. [Medline] [CrossRef]

39. Yang HW, Hwang KJ, Kwon HC, Kim HS, Choi KW, Oh KS. Detection of reactive oxygen species (ROS) and apoptosis in human fragmented embryos. Hum Reprod 1998; 13: 998-1002. [Medline] [CrossRef]

40. Van Remmen H, Ikeno Y, Hamilton M, Pahlavani M, Wolf N, Thorpe SR, Alderson NL, Baynes JW, Epstein CJ, Huang T-T, Nelson J, Strong R, Richardson A. Life-long reduction in MnSOD activity results in increased DNA damage and higher incidence of cancer but does not accelerate aging. Physiol Genomics 2003; 16: 29-37. [Medline] [CrossRef]

41. Takeda A. Manganese action in brain function. Brain Res Brain Res Rev 2003; 41: 79-87. [Medline] [CrossRef]

42. Kehres DG, Maguire ME. Emerging themes in manganese transport, biochemistry and pathogenesis in bacteria. FEMS Microbiol Rev 2003; 27: 263-290. [Medline] [CrossRef]

43. Li S, Lu L, Liao X, Gao T, Wang F, Zhang L, Xi L, Liu S, Luo X. Manganese elevates manganese superoxide dismutase protein level through protein kinase $\mathrm{C}$ and protein tyrosine kinase. Biometals 2016; 29: 265-274. [Medline] [CrossRef]

44. Aguirre JD, Culotta VC. Battles with iron: manganese in oxidative stress protection. $J$ Biol Chem 2012; 287: 13541-13548. [Medline] [CrossRef]

45. Meister A. Selective modification of glutathione metabolism. Science 1983; 220: 472-477. [Medline] [CrossRef]

46. Wang W-H, Day BN. Development of porcine embryos produced by IVM/IVF in a me- 
dium with or without protein supplementation: effects of extracellular glutathione. Zygote 2002; 10: 109-115. [Medline] [CrossRef]

47. Meister A, Anderson ME. Glutathione. Annu Rev Biochem 1983; 52: 711-760. [Medline] [CrossRef]

48. Abeydeera LR, Wang W-H, Cantley TC, Prather RS, Day BN. Glutathione content and embryo development after in vitro fertilisation of pig oocytes matured in the presence of a thiol compound and various concentrations of cysteine. Zygote 1999; 7: 203-210. [Medline] [CrossRef]

49. McEvoy TG, Coull GD, Broadbent PJ, Hutchinson JS, Speake BK. Fatty acid composition of lipids in immature cattle, pig and sheep oocytes with intact zona pellucida. $J$ Reprod Fertil 2000; 118: 163-170. [Medline] [CrossRef]

50. Ribarov SR, Benov LC. Relationship between the hemolytic action of heavy metals and lipid peroxidation. Biochim Biophys Acta 1981; 640: 721-726. [Medline] [CrossRef]
51. Lu L, Luo XG, Ji C, Liu B, Yu SX. Effect of manganese supplementation and source on carcass traits, meat quality, and lipid oxidation in broilers. J Anim Sci 2007; 85: 812-822. [Medline] [CrossRef]

52. Bansal AK, Kaur AR. Cooperative functions of manganese and thiol redox system against oxidative stress in human spermatozoa. J Hum Reprod Sci 2009; 2: 76-80. [Medline] [CrossRef]

53. Ogawa B, Ueno S, Nakayama N, Matsunari H, Nakano K, Fujiwara T, Ikezawa Y, Nagashima H. Developmental ability of porcine in vitro matured oocytes at the meiosis II stage after vitrification. J Reprod Dev 2010; 56: 356-361. [Medline] [CrossRef]

54. Zhang S, Tang B, Fan C, Shi L, Zhang X, Sun L, Li Z. Effect of DNMT inhibitor on bovine parthenogenetic embryo development. Biochem Biophys Res Commun 2015; 466 : 505-511. [Medline] [CrossRef] 